\title{
PENGEMBANGAN MODUL IDENTIFIKASI INSEKTA DI BKPH KEDUNGGALAR KECAMATAN PITU NGAWI PADA MATA KULIAH TAKSONOMI HEWAN INVERTEBRATA
}

\author{
Nur Aini Kusumaningrum \\ SMK Kesehatan Ponorogo \\ Email:poesky86@gmail.com \\ Diterima 2 Agustus 2015 disetujui 24 Oktober 2015
}

\begin{abstract}
Invertebrate taxonomy module courses are limited and textual. Invertebrate taxonomy module that is not based on contextual research. Ngawi Pitu forest can be used as a location for research, because of the diversity of existing invertebrates. The research aims to develop insect identification modules on subjects Taxonomy invertebrate insightful context. Module development using the 4D model (Define, Design, Development, Dissemination). The products produced in the form of modules with product validation to experts and tested on students. The results obtained expert ideals $79 \%$ in both categories. Results of tests on subjects obtained ideals $72 \%$ with the good category. The trial results states : 1) modules developed well and fit for use with the improvement of writing, 2 ) students easily recognize examples of insects as obtained from the forest and the surrounding environment. Suggestion development need to be large-scale trials to determine the effectiveness of the module as well as need to be developed on a wider material .
\end{abstract}

Keywords: identification, insects, modules

\section{PENDAHULUAN}

Ketersediaan sumber belajar yang semakin banyak diperlukan oleh mahasiswa sering merujuk pada sumber referensi relevan. Ketersediaan modul yang ditulis sendiri oleh dosen masih terbatas, belum adanya modul yang dikemas berdasarkan hasil penelitian, menyebabkan pembelajaran masih bersifat tekstual.

Mata kuliah Taksonomi Invertebrata merupakan mata kuliah wajib yang membahas penyusunan organismeorganisme ke dalam kelompok-kelompok yang tepat dengan menggunakan namanama yang sesuai dan benar berdasarkan ciri-ciri, dan kesamaan sifat. Ketersediaan modul pada mata kuliah taksonomi invertebrata sangat terbatas, khususnya modul yang disusun sendiri oleh dosen mata kuliah dan berdasarkan hasil penelitian.

Tujuan penelitian untuk mengembangkan produk berupa modul yang disusun berdasarkan hasil identifikasi insekta yang dilakukan di hutan Pitu Ngawi.
Modul merupakan suatu cara pengorganisasian materi pelajaran yang memperhatikan fungsi pendidikan (Santyasa, 2009). Modul dapat dipandang sebagai paket program pengajaran yang terdiri dari komponen-komponen yang berisi tujuan belajar, bahan pelajaran, metode belajar, alat atau media, serta sumber belajar dan sistem evaluasinya.

Tujuan penyusunan atau pembuatan modul antara lain agar peserta didik dapat belajar secara mandiri tanpa atau dengan bimbingan pendidik yang minimal, agar peran pendidik tidak terlalu dominan dan otoriter dalam kegiatan pembelajaran, melatih kejujuran peserta didik, mengakomodasi berbagai tingkat dan kecepatan belajar peserta didik. Peserta didik yang kecepatan belajarnya tinggi, maka mereka dapat belajar lebih cepat serta menyelesaikan modul dengan lebih cepat pula, sebaliknya bagi yang lambat maka mereka dapat mengulanginya kembali, agar peserta didik mampu mengukur sendiri 
tingkat penguasaan materi yang telah dipelajari (Prastowo, 2011).

$$
\text { Spesifikasi modul yang }
$$

dikembangkan berdasarkan hasil penelitian identifikasi insekta selanjutnya diawetkan menjadi insektarium sehingga modul mengandung wawasan kontekstual dan foto dan awetan insekta disajikan secara faktual serta mudah ditemui disekitar mahasiswa.

\section{METODE}

Penelitian menggunakan metode penelitian dan pengembangan atau Research and Development dengan mengadopsi model pengembangan 4-D (Define, Design, Development, Dissemination) dari Thiagarajan, Semmel, dan Semmel 1974 (Trianto, 2010). Gambar 1 merupakan model pengembangan perangkat pembelajaran 4D.

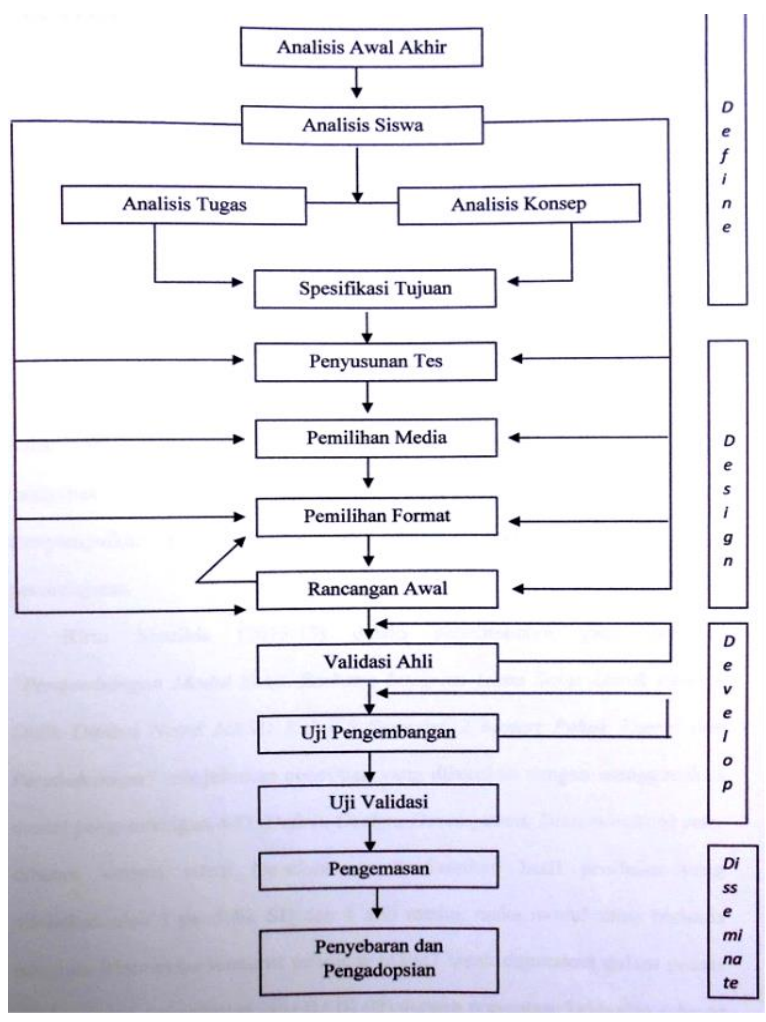

Gambar 1. Model Pengembangan Perangkat Pembelajaran 4-D (Thiagarajan, Semmel, dan Semmel , 1974)

Kelayakan modul dilakukan validasi terhadap dua orang pakar taksonomi invertebrate. Uji coba produk modul dilakukan terhadap kelompok kecil mahasiswa yang menempuh mata kuliah Taksonomi Invertebrata, dengan kriteria 3 mahasiswa prestasi tinggi, 3 mahasiswa prestasi sedang, dan 3 mahasiswa prestasi rendah. Prestasi mahasiswa ditentukan berdasarkan indeks prestasi.

Lembar evaluasi hasil produk dianalisis secara diskriptif diperoleh persentase keidealan yang menunjukkan kualitas modul. Persentase keidealan dihitung dengan rumus sebagai berikut.

Presentase ideal $=\frac{\text { skor hasil penilaian }}{\text { skor tertinggi ideal }} \times 100 \%$

\section{HASIL DAN PEMBAHASAN}

Pengembangan modul dengan model pengembangan 4-D yang dengan hasil sebagai berikut.

Tahap define adalah tahap untuk menetapkan dan mendefinisikan syaratsyarat pembelajaran. Tahap define mencakup lima langkah pokok, yaitu:

1. Analisis ujung depan

Analisis ujung depan bertujuan untuk menetapkan masalah dasar yang menjadi alasan pengembangan modul. Hasil analisis akan diperoleh gambaran fakta, harapan dan alternatif penyelesaian masalah dasar, yang memudahkan dalam penentuan atau pemilihan bahan ajar yang dikembangkan. Pengembangan modul diawali dengan melakukan identifikasi insekta di Hutan Pitu BKPH Kedunggalar Kabupaten Ngawi, dan mengumpulkan referensi yang relevan

2. Analisis peserta didik

Analisis peserta didik merupakan telaah tentang karakteristik mahasiswa yang sesuai dengan desain pengembangan perangkat pembelajaran. Kegiatan yang dapat dilakukan adalah wawancara terhadap mahasiswa semester gasal untuk mengetahui kekurangan dan kelebihan misalnya cara belajar, ketersediaan 
modul, kekurangan modul yang digunakan saat ini dalam pembelajaran mata kuliah Taksonomi Hewan Invertebrata dan apakah berdampak pada peningkatan prestasi mahasiswa.

3. Analisis konsep

Analisis konsep dilakukan untuk mengidentifikasi konsep pokok yang akan diajarkan, menyusunnya dalam bentuk hirarki, dan merinci konsepkonsep pengembangan modul. Kegiatan yang dilakukan adalah menyusun konsep atas materi-materi yang digunakan sebagai sarana pencapaian kompetensi dasar dan standar kompetensi.

Analisis yang dilakukan adalah (1) analisis standar kompetensi dan kompetensi dasar mata kuliah Taksonomi Hewan Inverterbrata yang bertujuan untuk menentukan jumlah dan jenis bahan ajar, (2) analisis sumber belajar, yakni mengumpulkan dan mengidentifikasi sumber-sumber mana yang mendukung pengembangan modul.

4. Analisis tugas

Analisis tugas bertujuan untuk mengidentifikasi keterampilanketerampilan utama yang akan dikaji oleh peneliti dan menganalisisnya ke dalam himpunan keterampilan tambahan yang mungkin diperlukan. Kegiatan yang dilakukan adalah menyusun soal-soal evaluasi dalam modul berupa tugas, soal-soal pilihan ganda, maupun uraian.

5. Perumusan tujuan pembelajaran

Perumusan tujuan pembelajaran berguna untuk merangkum hasil dari analisis konsep dan analisis tugas. Analisis konsep menentukan isi atau materi pada modul, dilanjutkan analisis tugas yang memuat tugas untuk evaluasi. Kumpulan objek tersebut disatukan dan menjadi dasar untuk menyusun modul.

Tahap Design atau perancangan bertujuan untuk merancang perangkat pembelajaran. Empat langkah yang dilakukan yaitu:

1. Penyusunan tes acuan patokan

Penyusunan tes acuan patokan merupakan langkah yang menghubungkan antara tahap pendefinisian (define) dengan tahap perancangan (design). Penyusunan tes acuan patokan dilakukan dengan merumuskan Standar kompetensi, kompetensi dasar, tujuan pembelajaran pada mata kuliah Taksonomi Hewan Invertebrata pokok bahasan insekta.

2. Pemilihan media

Pemilihan media digunakan adalah foto-foto hasil identifikasi serta insektarium sebagai media kontekstual dari hasil penelitian atau identifikasi dan didukung dengan gambar-gambar yang relevan yang bersumber dari internet.

3. Pemilihan format (format selection)

Pemilihan format yang digunakan dalam penyusunan modul adalah format yang dipilih memenuhi kriteria menarik, memudahkan dan membantu dalam pembelajaran Taksonomi Hewan Invertebrata

4. Rancangan awal (initial design)

Rancangan awal yang dimaksud adalah rancangan seluruh perangkat modul yang dikerjakan sebelum uji coba dilaksanakan. Rancangan adalah proposal atau draft modul yang akan di revisi

Tahap Development atau pengembangan adalah tahap untuk menghasilkan produk pengembangan yang dilakukan melalui dua langkah, yaitu: (1) penilaian ahli yang diikuti dengan revisi, (2) uji coba pengembangan.

Tujuan tahap pengembangan adalah untuk menghasilkan bentuk akhir modul setelah melalui revisi berdasarkan masukan pakar/ahli/praktisi dan data hasil uji coba. Langkah yang dilakukan adalah sebagai berikut. 
1. Validasi ahli/praktisi

Penilaian para pakar/praktisi terhadap perangkat pembelajaran mencakup: format, bahasa, ilustrasi dan isi. Validasi oleh ahli penyusunan modul dan ahli taksonomi invertebrata.

2. Uji coba pengembangan

Uji coba lapangan dilakukan untuk memperoleh masukan langsung berupa respon, reaksi, komentar mahasiswa, dan para reviewer terhadap modul yang telah disusun. Uji coba dilakukan menggunakan instrumen penelitian terhadap mahasiswa yang menempuh mata kuliah taksonomi invertebrata, instrumen penelitian untuk ahli penyusunan modul, instrumen penelitian untuk ahli isi, dan instrumen penelitian untuk dosen mata kuliah Taksonomi Hewan Invertebrata

Hasil uji coba penilaian modul oleh pakar pertama diperoleh rentang skor $67,998<79 \leq 83,994$ dan persentase ideal $79 \%$ dengan kategori baik. Hasil penilaian modul oleh pakar kedua diperoleh rentang skor 67,998 < $71 \leq 83,994$ dan persentase ideal $71 \%$ dengan kategori baik. Hasil penilaian modul oleh dosen mata kuliah diperoleh rentang skor $67,998<72 \leq 83,994$ dan presentase ideal $72 \%$ dengan kategori baik. Hasil penilaian mahasiswa diperoleh rentang skor $67,998<74 \leq$ 83,994 dan persentase ideal $74 \%$ dengan kategori baik. Berdasarkan hasil penilaian modul yang dikembangkan layak/dapat digunakan sebagai bahan ajar pembelajaran Taksonomi Invertebrata.

Hal tersebut sesuai dengan kajian pustaka yang relevan dari penelitian (Anafiah, 2013) dan penelitian (Maulida, 2013) yang juga mengadopsi model pengembangan 4-D modul yang dikembangkan layak/dapat digunakan dalam pembelajaran.

Respon dari mahasiswa juga menunjukkan hasil yang relevan dengan literatur dari penelitian (Setyaningrum et all, 2012) mahasiswa senang dan merasa terbantu dengan adanya modul karena dapat memudahkan belajar secara mandiri.

\section{SIMPULAN}

Berdasarkan hasil penelitian pengembangan modul taksonomi dengan subjek insekta di hutan Pitu Kedungggalar Ngawi, modul taksonomi invertebrata materi insekta dikategorikan baik dan layak digunakan dalam pembelajaran.

\section{DAFTAR PUSTAKA}

Andi Prastowo. (2011). Panduan Kreatif Membuat Bahan Ajar Inovatiaf. Yogyakarta: Diva Press.

Dyah Setyaningrum, Siti Harnina Bintari, Priyantini Widiyaningrum. 2012. Pengembangan Perangkat Pembelajaran Biologi Berorientasi LIFE SKILLS Memanfaatkan Bahan Baku Kedelai Lokal.

I Wayan Santyasa. (2009). Metode Penelitian Pengembangan Dan Teori Pengembangan Modul. Makalah disajikan dalam pelatihan bagi para pendidik TK, SD, SMP, SMA, dan SMK tanggal 12-14 Januari 2009, di Kecamatan Nusa Penida Kabupaten Klungkung.

Kuni Anafiah. (2013.) Pengembangan Modul Ekosistem Berorientasi Kewirausahaan Untuk SMA/MA Kelas X. Skripsi tidak diterbitkan. Yogyakarta: Program Studi Pendidikan Kimia Universitas Islam Negeri Sunan Kalijaga

Ririn Maulida. (2013). Pengembangan Modul Pembelajaran Sains Berbasis Integrasi Islam-Sains untuk Peserta Didik Difabel Netra MI/SD Kelas 5 Semester 2 Materi Pokok Energi dan Perubahannya. Skripsi tidak diterbitkan. Yogyakarta: Program Studi Pendidikan Kimia Universitas Islam Negeri Sunan Kalijaga

Trianto. 2010. Model Pembelajaran Terpadu. Jakarta: Bumi Aksara 